\title{
DETERMINATION OF PRIORITIES IN APPAREL PURCHASING FROM PRIVATE SALE WEBSITES
}

\author{
Canan Saricam*, Nazan Erdumlu \\ Istanbul Teknik Universitesi, Istanbul, Turkey \\ *Corresponding Author E-Mail: saricamc@itu.edu.tr
}

\begin{abstract}
:
In the fast-changing internet era, private sale websites attracted an enormous interest from the consumers in especially online marketing of apparel goods. The retailers may garner more benefit if the prior issues for the consumers when they are purchasing apparel products online is known. Reviewing the literature, this study presents the factors in three groups in a hierarchical manner considering the multidimensional aspect of online purchasing of apparel products from private sale websites and then determines the prior issues for the consumers by making pairwise comparisons among these factors using analytical hierarchy process on a sample group of 100 Turkish respondents. The findings revealed that "privacy/security" in terms of online shopping criteria, "product information" in terms of apparel products criteria, and "discount ratio" in terms of private shopping criteria took highest scores of importance when the aspects were analyzed individually. Nonetheless, the parameters regarding the online shopping criteria were found to be more important than the criteria regarding the apparel products and private shopping criteria. In the end, it was also observed that these items that were found to have highest importance were actually corresponding to the risks of the situation.
\end{abstract}

\section{Keywords:}

Online Private Shopping, Analytical Hierarchy Process, Apparel products

\section{Introduction}

First initiated in 2001 by French market leader Ventee-privee. com [1], private sale websites have been favored almost everywhere in the world and they have presented a unique niche with an impressive growth of revenue [2]. Selling mostly fashion and small selection of designers' fashion type of products, this niche is particularly important for apparel retailers [3]. The classification of the offerings of the private sale websites and determination of the priorities of these offerings for the consumers are important for the apparel retailers when they are making critical decisions about the implementation of useful marketing strategies.

Private sale websites are the online shopping platforms that present the consumers with a broad range of products from different brands at affordable prices [4]. But they have some distinguishing features from other online shopping websites and thus have certain dynamics related with regard to sales marketing. The private sale websites organize special campaigns for their members, in which products from famous brands are offered at affordable prices as bargains [1]. Besides this, the appetite of the members for these campaigns is enhanced by organizing the campaigns in different frequencies and keeping them valid only for a limited period of time. Thus, the private sale websites should provide good quality for the consumers in terms of being an online shopping platform and acting as an open sale market.

On the other hand, usually apparel products are sold via these websites. Thus the private sale websites should take care about the selling apparel products online as it presents with certain dynamics. In fact, it is known that most people avoid purchasing apparel online because of the size and fit issues [5]. Considering the points stated above, three aspects of private sale websites, which are online shopping platforms providing special offerings for the consumers and selling usually apparel type of products, should be taken into account in the determination prior issues for the consumers.

Actually, there are many studies that investigated the quality characteristics of online shopping and the relationship between these characteristics and consumers' intention to purchase, while a few studies attempted to determine the priorities of the consumers in online shopping in most of which AHP was used successfully. Although not high in number, some studies focused on apparel products in online shopping. Finally, few studies specifically investigated the consumers' characteristics in purchasing from private sale websites. In none of the studies, it was attempted to identify which parameters are most important for the consumers when they make apparel purchasing from private sale websites however.

This study aims to ascertain the prior issues in apparel purchasing from private sale websites considering the subdimensions, which are being an online shopping platform, allowing private sales and selling apparel products and. To this aim, a hierarchical structure of criteria related with these factors corresponding to the multidimensional aspects of online purchasing of apparel products from private sale websites were identified and then analytic hierarchy process (AHP) was applied on the sample group of Turkish consumers in order to rank these criteria. 


\section{Background Literature}

The studies about online purchasing in literature mostly concentrated on the quality characteristics of the online shopping. Gotzamani and Tzavlopoulos [6] developed a framework for evaluating e-commerce quality based on review in the literature. Within this respect, the authors classified the factors that affect e-commerce quality into three parts: quality, website quality, and e-service quality. Nonetheless, the studies in the literature that investigated the relationship between online shopping and consumer behavior were found out to be focusing on mainly service quality characteristics of online shopping.

\subsection{Quality characteristics of online shopping}

Online service quality, which was defined as the consumers' overall evaluation and judgment of excellence and quality of e-service offerings in the virtual market place [7], was the concern of many researchers who developed specific scales for online service quality that took their roots from SERVQUAL developed by Parasuraman, Zeithaml, and Berry [8]. WebQual [9], E-S-Qual [10], and SITEQUAL [11] were developed for measuring the online service quality. Long and McMellon [12] added communications and purchase process (ordering/ shipping/packaging) to SERVQUAL dimensions in order to determine the online service quality. Zeithaml, Parasuraman, and Malhotra [13] integrated the quality characteristics regarding the purchase and delivery by defining e-SQ. Wolfinbarger and Gilly [14] developed an online retail quality scale eTailQ consisting of 14 items capturing four dimensions: website design, security/privacy, fulfillment/reliability, and customer service. On the other hand, Cho and Park [15] developed an instrument for measuring e-commerce consumer satisfaction and searched for the influence of the attributes of e-commerce such as product information, consumer service, purchase result and delivery, site design, purchasing process, product merchandising, delivery time and charge, payment methods, ease of use, and additional information service.

\subsection{Quality characteristics of online apparel shopping}

While discussing the quality characteristics of online shopping, the website attributes and the dimensions of website quality were stated to differ based on the product and function of the site, however [16]. In parallel with this, some researchers investigated the website quality specifically in apparel purchasing. Kim and Stoel [16] examined the website quality for apparel retailers in order to determine the significant quality dimensions in shopper satisfaction adapting Loiacono's WebQualTM instrument. Ha and Stoel [17] developed a model for online apparel retailing covering the factors such as website content/functionality, customer service, privacy/security, and experiential/atmospheric. Kim, Kim, and Lennon [18] developed E-A-S-QUAL in order to capture extensive service attributes available on apparel retail websites. E-A-S-QUAL covered the quality attributes specific to the apparel purchasing such as availability of size chart, product description, and the quality attributes specific to e-retailing such as availability under fulfillment, payment and shipping methods, personalization, suggestion for items, and promotions. Having established content analysis on online apparel shopping, including apparel specific terms such as sizing, style and fashionability, item care, texture, and fabric hand, Park and Stoel [19] underlined the importance of the information provided to the consumer stating that information dissolves the risks raised by doing the shopping online.

\subsection{Quality characteristics of apparel products}

There are numerous studies that investigated the important quality attributes of apparel products. In fact, the seven factors of apparel products were counted as performance, components, garment care, appearance, construction or workmanship, style or fashion, and fit [20]. Abraham-Murali and Littrell [21] claimed that the important attributes of apparel products were fabric and garment construction, care, value, style, and service. On the other hand, Forsythe [22] reported that apparel products had the extrinsic cues for quality such as brand name, price, package, and store image and intrinsic cues such for quality such as design, style, fabric type, fiber content, and construction details. North, Vos, and Kotze [23] indicated that style was the most important attribute for the female consumers when purchasing apparel products.

\subsection{Studies about private shopping}

Being a new concept, there are quite limited studies within the literature regarding private shopping. Baybars and Ustundagli [24] investigated whether the private shopping behavior had a relationship with the shopping motive of price discounts and the personal characteristics, which were the consumer requirements for uniqueness and innovativeness. Ayadi, Giraud, and Gonzalez [1] identified the shopping from these websites as repeated impulsive buying and investigated the control mechanisms that consumers used when confronted with repeated temptations in an online private sales context using a qualitative research method. Kim and Martinez [3] divided the shoppers of private sale websites into distinct categories based on their levels of fashion leadership. Martinez [25] investigated the impacts of shopping characteristics and perceived website quality on purchase intention from a private sale website by conducting a survey among 164 female respondents. Saricam [26] investigated the factors influencing the acceptance of these websites by the consumers using technology acceptance model.

Within this premise, the features of online shopping were mostly specified as service quality variables and additional parameters were added when it was concentrated on different types of websites or products. Thus, the quality parameters for online apparel purchasing from private shopping websites should be established taking into consideration the parameters related with online shopping, private sale websites, and apparel products. Nonetheless, the studies mentioned here investigated the influence of the parameters on the satisfaction or intention to buy, but they did not analyze the parameters according their priorities.

\subsection{Analytic Hierarchy Process}

Being a multicriteria decision-making tool that structures complex problems in the form of hierarchical manner considering both 
the quantitative and qualitative aspects [27]; AHP was used in determination of the priorities in and quality of online shopping websites and retailing because of being a simple, easy to use, and flexible tool proposed by Saaty $[28,29]$. Hasan and Abuelrub [30] developed a hierarchy for the website quality with four main categories: content, design, organization, and user friendliness. Kong and Liu [31] applied fuzzy analytic hierarchy process to evaluate success factors of e-commerce. The success factors were determined as trust, system quality, content quality, online service, and use whereas the subcriteria were identified as security and privacy for trust; visual appearance, response time, page loading, available hours for system quality; upto-datedness, understandability, timeliness, preciseness for content quality; order tracking, account maintenance, payment alternatives for online services; and information, transaction, the disabled service, and FAQ for use. Cebi [32] focused on design quality of online shopping websites and developed a quality evaluation model with six main design parameters and 19 subdesign parameters. The parameters in this study were selected as ease of use, ease of learning, memorability for usability; layout, graphics, text for visual aspects; system availability, speed, accessibility, navigation for technical adequacy; reliability, accuracy, privacy for security and privacy; contact info, online help, responsiveness for communication; reputation, sustainability, and currency for prestige. On the other hand, Huang and Feng [33] focused on identifying the determinants of logistic service quality on retailing delivery service for online shopping adding the quality factors such as information quality, ordering procedures, timeliness, order conditions, and order discrepancy. Moreover, some studies using AHP concentrated on specific type of websites such as auction websites [34, 35] and online travel websites [36].

Thus, AHP has proven itself as an effective tool for the determination of priorities with many evidences from literature. Nonetheless, there is no study in the literature that deals with specifically the priorities of consumers in online purchasing of apparel from private sale websites.

\section{Methodology}

The two-level hierarchical structure (shown in Figure 1) was established based on the previous studies within the literature. Table 1 that shows the criteria (Level 1), subcriteria (Level 2), the definitions of the criteria, and the references in which they were proposed to be important factors.

The data for the study was obtained from an online survey conducted among the end consumers of private shopping. A questionnaire having two parts was used within the survey. The first part of the questionnaire was related to the sample profile about the social and demographic characteristics. The second part involved the questions for pairwise comparisons for three main and 13 sub-criteria instead of matrices of AHP. In the questionnaire, the respondents were required to compare two criteria according to five options given in Table 2.

Although Saaty [29] proposes to use 9 point scales, the scale in Table 2 was preferred for the study. Actually, there are many studies that use different scales for the implementation of AHP process [38-42]. It was found out that mostly respondents did not use more than three judgments when they compared up to four elements [41]. Moreover, pairwise comparisons were reported to be difficult when more than three choices were available [42]. According to Miller [43], the psychological limit on the human capacity for processing information is $7 \pm 2$ items [42]. Thus, the scale above was preferred as it was tested with the unskilled users who might be confused with larger scales.

After collecting the results of the questionnaire, the data was subjected to elimination and the respondents who failed to make ranking by giving the same grade to the questions in the same category were left out of assessment. This led to consider data from only 75 of 100 respondents. From the data from these 75 respondents, a pairwise comparison matrix called $A=(a i j)$ was established for each category in the first and second level of hierarchy using the geometric mean approach

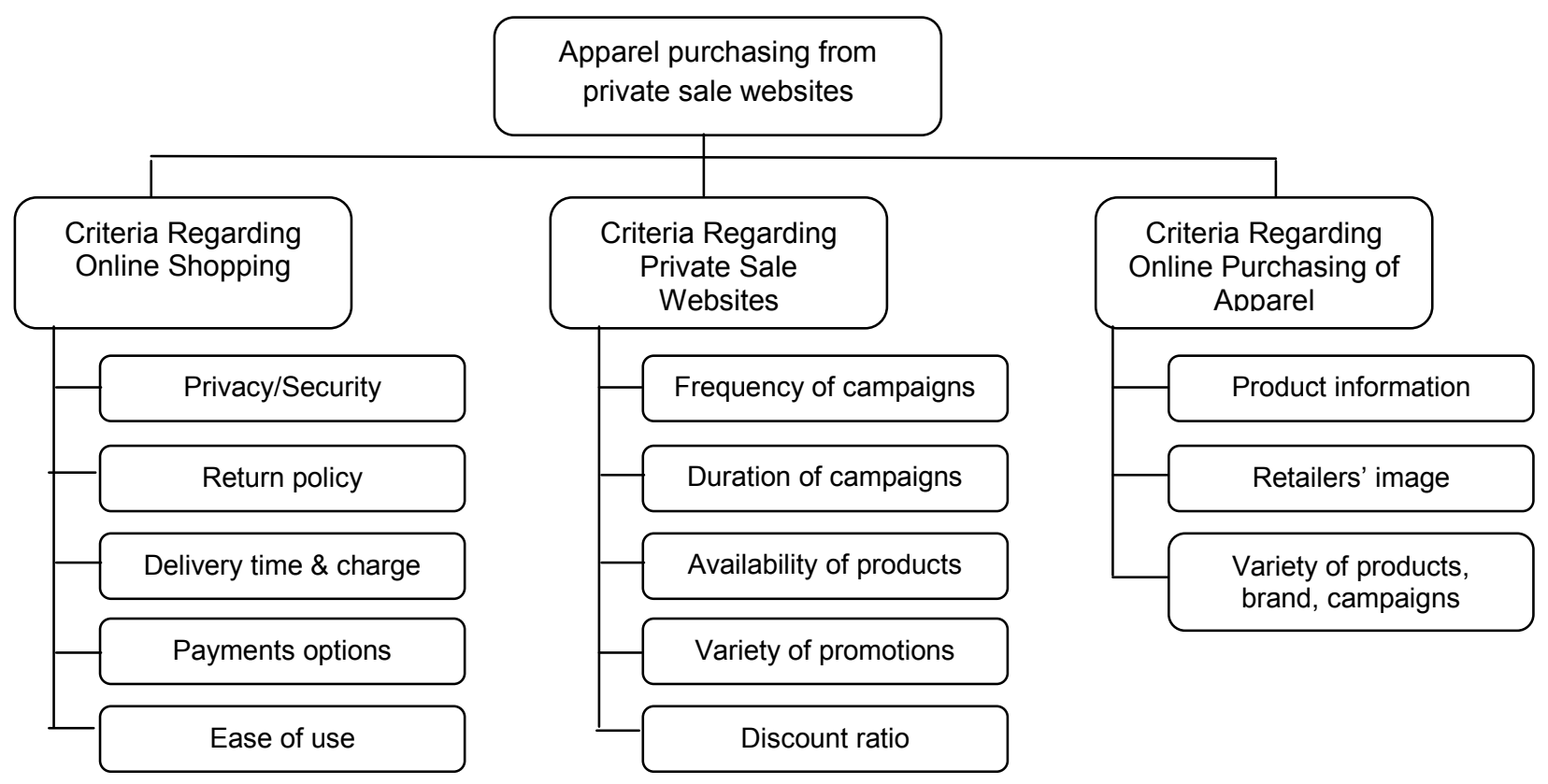

Figure 1. Hierarchical structure. 
Table 1. The criteria, the sub-criteria, their definitions and the references

\begin{tabular}{|c|c|c|c|}
\hline $\begin{array}{l}\text { Criteria } \\
\text { (Level 1) }\end{array}$ & $\begin{array}{c}\text { Sub-Criteria } \\
\text { (Level 2) }\end{array}$ & Definition & Reference \\
\hline \multirow{5}{*}{$\begin{array}{l}\text { Criteria } \\
\text { Regarding } \\
\text { Online } \\
\text { Shopping } \\
\text { (CROS) }\end{array}$} & Privacy/security(PS) & security of payments and privacy of the information given & [17] \\
\hline & Return Policy(RP) & terms and conditions related with returning and refunding & {$[18,19]$} \\
\hline & Delivery time, charge(DTC) & $\begin{array}{l}\text { delivery of the product in short and right period of time without } \\
\qquad \text { excessive charge }\end{array}$ & [15] \\
\hline & Payment options(PO) & usability and visual aspects of websites & [32] \\
\hline & Ease of use(EOU) & payment alternatives provided by website & {$[15,31,37]$} \\
\hline \multirow{5}{*}{$\begin{array}{l}\text { Criteria } \\
\text { Regarding } \\
\text { Private } \\
\text { Sale } \\
\text { Websites } \\
\text { (CRPS) }\end{array}$} & Discount ratio(DR) & selling the products at the prices with very deep discounts. & [25] \\
\hline & Frequency of campaign(FOC) & establishment of the campaigns frequently & {$[3,25]$} \\
\hline & Variety of promotions(VOP) & $\begin{array}{l}\text { promotions such as free shipping, one cart, gift cards, special } \\
\text { discount for the first time and invitations. }\end{array}$ & {$[1]$} \\
\hline & Availability of products(AOP) & Availability of products in different sizes and colors & [24] \\
\hline & Length of campaign(LOC) & time between the start and end of the campaigns & [25] \\
\hline \multirow{3}{*}{$\begin{array}{l}\text { Criteria } \\
\text { Regarding } \\
\text { Online } \\
\text { Purchasing } \\
\text { of Apparel } \\
\text { (CROPA) }\end{array}$} & Product information (PI) & $\begin{array}{l}\text { the images, photos and information provided regarding the } \\
\text { fabric structure, size and measures. }\end{array}$ & {$[15,18,19]$} \\
\hline & Retailers image (RI) & the perception of the product or brand by consumers & [32] \\
\hline & $\begin{array}{l}\text { Variety of product, brand, } \\
\text { campaigns (VPBC) }\end{array}$ & $\begin{array}{c}\text { the number of product type, product (style) and brand } \\
\text { presented at the same }\end{array}$ & [23] \\
\hline
\end{tabular}

Table 2. The scale used for pairwise comparison

\begin{tabular}{|c|c|c|c|}
\hline 5 Options in questionnaire & $\begin{array}{l}\text { Numerical } \\
\text { value of the } \\
\text { option }\end{array}$ & Definition & Explanation \\
\hline Criterion $\mathrm{A}$ is strongly more important than the criterion $\mathrm{B}$ & 5 & $\begin{array}{l}\text { Strong importance in } \\
\text { favor of } 1^{\text {st }} \text { criteria }\end{array}$ & \multirow{5}{*}{$\begin{array}{l}\text { If a criteria A has one } \\
\text { in from the index } \\
\text { on the left, when } \\
\text { compared with criteria } \\
B \text {, then } B \text { has the } \\
\text { reciprocal value when } \\
\text { compared to } A \text {. }\end{array}$} \\
\hline Criterion $A$ is more important than the criterion $B$ & 3 & $\begin{array}{l}\text { Moderate importance } \\
\text { in favor of } 1^{\text {st }} \text { criteria }\end{array}$ & \\
\hline Criterion $A$ and criterion $B$ are equally important & 1 & Equal importance & \\
\hline Criterion $B$ is more important than the criterion $A$ & $1 / 3$ & $\begin{array}{l}\text { Moderate importance } \\
\text { in favor of } 2^{\text {nd }} \text { criteria }\end{array}$ & \\
\hline Criterion $B$ is strongly more important than the criterion $B$ & $1 / 5$ & $\begin{array}{l}\text { Strong importance in } \\
\text { favor of } 2^{\text {nd }} \text { criteria }\end{array}$ & \\
\hline
\end{tabular}

[39] as geometric mean was reported to be the best approach in terms of combining the judgments of the group [44-45]. Each of the matrices was then translated into the corresponding largest eigen-value problem and was solved to find the unique priority weight for each criterion. The consistency was measured by calculating and comparing the consistency ratio $(\mathrm{CR})$ with the threshold value $<0.1$ [39]. Consistency ratio was calculated using Equation 1 [41]:

$$
\mathrm{CR}=\mathrm{Cl} / \mathrm{RI}
$$

where $\mathrm{Rl}$ is the random consistency index whose values change according to the number of items within the comparison matrix [31] and $\mathrm{Cl}$ represents the consistency index and is calculated using Equation 2:

$$
\mathrm{Cl}=\left(\Lambda_{\max }-n\right) /(n-1)
$$

where $n$ is the number of components evaluated in the pairwise comparison matrix, and $\lambda_{\max }$ is the largest eigen value characterizing the previous matrix. The final priority weight for the subcriteria was calculated by multiplying the priorities in the first and second level.

\section{Results}

A total of 75 responses were analyzed and the results revealed that $61.3 \%$ of the respondents were female whereas $38.7 \%$ were males. Most of the respondents were aged between "18 and 23" followed by the ones aged between "30-35" and "24-29," respectively. Besides, the majority of the respondents were undergraduates and they belonged to the income class of "low to moderate." Of them, $98.7 \%$ stated that they were 
purchasing from the internet, $94.5 \%$ stated that they were members of private sale websites, and finally $78.7 \%$ of them were purchasing apparel from the private sale websites.

The value of $\lambda_{\max }$ was very close to the number of criteria within the categories. The CR was 0.04 for the first level of hierarchy and got the values $0.02,0.01$, and 0.00 , respectively, for the categories in the second level of hierarchy. This confirmed that the evaluators can be considered as consistent.

In Table 3, it was seen that the criteria regarding online shopping is more important for the consumers than the criteria regarding private shopping and apparel purchasing online.
In the second level of hierarchy in Tables 4-6, "privacy/security," "return policy," and "delivery time and charge" were found to be more important than the "payment options" and "ease of use" in terms of online shopping. "Discount ratio" was observed to be the most important parameter within the criteria regarding private shopping followed by "variety of promotions." With respect to online purchasing of apparel from these websites, "product information" was seen to have higher importance than the "variety of product, brand, campaigns," and "retailers' image."

Table 7 shows the subcriteria, the criteria to which subcriteria are counted under, the weight of the criteria, the weights expressed

Table 3. Pairwise comparison judgment matrices of criteria for first level private shopping websites

\begin{tabular}{|c|c|c|c|c|}
\hline Apparel purchasing from private shopping websites & CROS & CRPS & CROPA & Priority \\
\hline The criteria regarding online shopping (CROS) & 1 & 2.44 & 2.56 & 0.54 \\
\hline The criteria regarding private shopping (CRPS) & 0.41 & 1 & 2.00 & 0.28 \\
\hline The criteria regarding online purchasing of apparel (CROPA) & 0.39 & 0.5 & 1 & 0.17 \\
\hline$\lambda=9.14, \lambda_{\max }=3.05, C l=0.2, C R=0.04$ & & & & \\
\hline
\end{tabular}

Table 4. Pairwise comparison judgment matrix for second level of hierarchy in CROS

\begin{tabular}{|l|c|c|c|c|c|c|}
\hline The criteria regarding online shopping (CROS) & PS & RP & DTC & EOU & PO & Priority \\
\hline Privacy/security(PS) & 1 & 2.54 & 2.55 & 2.95 & 2.21 & 0.38 \\
\hline Return Policy(RP) & 0.39 & 1 & 1.77 & 2.79 & 1.92 & 0.23 \\
\hline Delivery time, charge(DTC) & 0.39 & 0.57 & 1 & 2.19 & 1.43 & 0.17 \\
\hline Ease of use(EOU) & 0.34 & 0.36 & 0.46 & 1 & 0.81 & 0.10 \\
\hline Payment options(PO) & 0.45 & 0.52 & 0.7 & 1.24 & 1 & 0.13 \\
\hline$\lambda=25.53, \lambda_{\max }=5.11, \mathrm{Cl}=0.03, \mathrm{CR}=0.02$ & & & & & \\
\hline
\end{tabular}

Table 5. Pairwise comparison judgment matrix for second level of hierarchy in CRPS

\begin{tabular}{|l|c|c|c|c|c|c|}
\hline The criteria regarding private shopping (CRPS) & FOC & LOC & AOP & VOP & DR & Priority \\
\hline Frequency of campaign(FOC) & 1 & 1.37 & 0.66 & 0.61 & 0.52 & 0.15 \\
\hline Length of campaign(LOC) & 0.73 & 1 & 0.72 & 0.68 & 0.53 & 0.14 \\
\hline Availability of products(AOP) & 1.52 & 1.39 & 1 & 0.99 & 0.80 & 0.22 \\
\hline Variety of promotions(VOP) & 1.65 & 1.48 & 1.01 & 1 & 1.08 & 0.24 \\
\hline Discount ratio(DR) & 1.93 & 1.87 & 1.25 & 0.92 & 1 & 0.26 \\
\hline$\lambda=25.15, \lambda_{\max }=5.03, \mathrm{Cl}=0.01$, & & & CR=0.01 \\
\hline
\end{tabular}

Table 6. Pairwise comparison judgment matrix for second level of hierarchy in CROPA

\begin{tabular}{|c|c|c|c|c|}
\hline The criteria regarding online purchasing of apparel (CROPA) & PI & $\mathbf{R I}$ & VPBC & Priority \\
\hline Product information $(\mathrm{PI})$ & 1 & 1.94 & 1.72 & 0.48 \\
\hline Variety of product, brand,campaigns (VPBC) & 0.58 & 1.11 & 1 & 0.28 \\
\hline$\lambda=9.00, \lambda_{\max }=3.00, \quad C l=0.00, C R=0.00$ & & & & \\
\hline
\end{tabular}


in percentage, and the ranks determined considering these weights.

In Table 7, it is seen that the top three criteria belonged to the criteria regarding online shopping, which confirmed the previous analysis. Although the criteria regarding private shopping were found to be more important than the criteria regarding apparel products in previous analysis, it was seen that most of the criteria that belonged to the category of apparel purchasing were more important than the criteria regarding the purchasing from private sale websites. Nonetheless, the number of criteria in two categories, which are purchasing from private sale websites or private shopping and apparel purchasing are not equal to each other.

When the final priority weights are considered, it is seen that "privacy/security" is the most important criteria for the consumers when they purchase online. It is followed by "return policy" and "delivery time and charge." These three parameters are actually related to the ability of the website to provide accurate service on-time and they actually point out the risks of online purchasing. The fourth criterion was seen to be "giving product information," which is stated to be one of the most important parameters in apparel purchasing because of the size and fit issues. Then comes the "discount ratio," which is one of the distinctive characteristics of the private sale websites. It was also seen that the parameter "variety of promotions" took the 10th rank. The "length of the campaign" and "frequency of the campaign" occupied the 12th and 13th ranks, being the least important parameters.

Considering the ranking of the parameters, it can be stated that the consumers give highest importance to the factors which they thought that they are risky. Nonetheless, the characteristics of private sale websites that increase their attractiveness in terms of consumer perspective are also important for the consumers.

\section{Discussion}

This study puts forward the factors related with online shopping of apparel products from private sale websites. Moreover, it presents the factors in a hierarchical manner allowing for determining the prior issues.

In the study, it was found out that the criteria related with online shopping are much more important than the criteria related with private shopping or apparel products. Specifically, the factors related with the risky parameters of online shopping got the highest scores. "Privacy/security" got the highest rank in importance. This result was confirmed by the previous studies in literature. Privacy was stated to be a critical issue [46] and to have a strong impact on intention to purchase, satisfaction [18], and overall site quality [11]. Moreover, it was not surprising to get "return policy" as the second important factor because it was stated that the consumers might feel more comfortable and free of risk when the return policy was clearly identified [18]. Finally, "delivery time and charge" was a parameter that shows the ability to fulfill the requirements according to Yang and Fang [47] who stated that accurate order fulfillment and keeping the promise were among the primary service quality elements for customer satisfaction.

On the other hand, the fourth parameter was found to be "product information" whose importance was clearly depicted in the previous studies. In fact, the consumers stated that they did not to purchase online because of the inability to try on the garments, feel the fabric, and read the information on care and content labels [19]. Size, color, and fit were determined to be decreasing the perceived risk of apparel products [19].

"Discount ratio," which is one of the special offers of private sale websites, became the fifth important parameter. This finding was not surprising because Martinez [25] put forward

Table 7. Priorities and ranks of customer requirements

\begin{tabular}{|c|c|c|c|c|}
\hline Criteria & Sub-Criteria & Weight & Weight \% & Rank \\
\hline$(\mathrm{CROS})$ & Privacy/security(PS) & 0.205 & 20.50 & 1 \\
\hline (CROS) & Return Policy(RP) & 0.127 & 12.66 & 2 \\
\hline$(\mathrm{CROS})$ & Delivery time, charge(DTC) & 0.090 & 9.03 & 3 \\
\hline (CROPA) & Product information (PI) & 0.083 & 8.34 & 4 \\
\hline (CRPS) & Discount ratio(DR) & 0.072 & 7.18 & 5 \\
\hline (CROS) & Payment options(PO) & 0.070 & 7.03 & 6 \\
\hline (CRPS) & Variety of promotions(VOP) & 0.066 & 6.64 & 7 \\
\hline (CRPS) & Availability of products(AOP) & 0.060 & 6.05 & 8 \\
\hline$(\mathrm{CROS})$ & Ease of use(EOU) & 0.052 & 5.25 & 9 \\
\hline (CROPA) & Variety of product, brand, campaigns (VPBC) & 0.048 & 4.82 & 10 \\
\hline (CROPA) & Retailers image (RI) & 0.043 & 4.31 & 11 \\
\hline (CRPS) & Frequency of campaign(FOC) & 0.042 & 4.24 & 12 \\
\hline (CRPS) & Length of campaign(LOC) & 0.040 & 3.96 & 13 \\
\hline
\end{tabular}


the characteristics of the private sale websites to present bargain shopping, which was identified a providing best value for the money instead of purchasing low-priced items or below-average quality products. "Payment options" became the sixth important parameter in parallel with the findings of Koksal [37]. Although price was mentioned to be among the important factors, payment options might be really important to Turkish people and their selection of products. "Discount ratio" and "payment options" were followed by another criterion belonging to the factors related with private sale websites, which was "variety of promotions." In fact, private sale websites proposed a continuous stream of promotions to consumers [1], including unique shopping experiences for premium members such as being able to start shopping earlier than the rest [3]. The selection of variety of promotions as a prior issue may be because of the feeling of the consumers being special through personalization since they were provided special offers by private sale websites. In fact, according to Kim, Kim, and Lennon [18], personalization is becoming more important in terms of online service quality since personalization is giving personal attention to consumers and it presents empathy dimension of service quality.

Nonetheless, it was interesting to see that retailers' image occupied the lower ranks. Although private sale websites were stated to present bargain shopping of luxury items by Martinez [25] as stated previously, it was shown that the "discount ratios" was more important than the "retailers' image." Although this finding seems to be contrary to the findings of Baybars and Ustundagli [24], this situation may be aroused because of Turkish people were more price sensitive rather than brand sensitive, according to the report established by ACBielsen [48].

Finally, the practice of private sale websites to sell in limited period of time was not given high importance by the consumers although it was claimed that private sale websites increased the attractiveness of offers by providing unique and scarce products [24]. This reveals that the consumers do not evaluate their benefits from only one campaign instead they consider the overall benefits that they provide from the purchasing. Besides, the consumers in Turkey can be identified as self-regulated consumers or hyperopic consumers who are eager to follow the campaigns but control themselves more than the myopic consumers who show totally an impulse buying behavior as stated by Ayadi, Giraud, and Gonzalez [1].

\section{Conclusions}

The present study was conducted to determine the prior factors when apparel products are purchased online from the private sale websites, which is becoming increasing trend among the retailers for marketing nowadays. Obtained from the application of $\mathrm{AHP}$, the results addressed the most important factors with a ranking among them in purchase decisions. Considering the findings of the study, the retailers can develop better marketing strategies in order to serve the consumers better. On the other hand, this hierarchical structure can be used as a base for the future studies that concentrates on different type of products.
Nonetheless, the data from the study was taken from a sample group of Turkish consumers who are accustomed to online shopping experience and thereby the potential customers of private sale websites. The preferences of the consumers may change for the other consumers in different countries with different social and economic backgrounds and habits.

For future studies, the detail level within the hierarchy can be increased in order to detect the main reasons behind the factors if they involve experienced people. Moreover, the prior issues may be investigated for finding out the influence of the social and demographic characteristic on the selections of the consumers. Finally, the framework and the findings of this study can be used for a comparative study that can be established in different parts of the world.

\section{References}

[1] Ayadi, N., Giraud, M., Gonzalez, C. (2013). An investigation of consumers' self-control mechanisms when confronted with repeated purchase temptations: Evidence from online private sales, Journal of Retailing and Consumer Services, 20, 272-281.

[2] Martinez, B., Kim, S. (2012). Predicting purchase intention for private sale sites, Journal of Fashion Marketing and Management, 16(3), 342-365.

[3] Kim, S., Martinez, B. (2013). Fashion consumer groups and online shopping at private sale sites, International Journal of Consumer Studies, 37, 367-372.3

[4] Dabhade, A.(2008). Antecedents of older consumers' internet shopping for apparel products: Perceived risk and benefits and shopping orientation, (A Master of Science Thesis), Auburn University.

[5] Kim, D.E., LaBat, K. (2013). Consumer experience in using $3 D$ virtual garment simulation technology, The Journal of The Textile Institute, 104(8), 819-829.

[6] Gotzamani, K.D., Tzavlopoulos, Y.E. (2009). Measuring E-commerce-quality: An exploratory review, International Journal of Quality and Service Sciences, 1(3), 271-279.

[7] Santos, J. (2003). E-Service Quality: A model of virtual service quality dimensions, Managing Service Quality, 13(3), 233-246.

[8] Parasuraman, A., Zeithaml, V.A., Berry, L.L. (1988), SERVQUAL: A multiple item scale for measuring consumer perceptions of service quality, Journal of Retailing, 49, 41-50.

[9] Loiacono, E.T., (2000). WebQual: A Website Quality Instrument, (Unpublished Doctoral Dissertation), University of Georgia.

[10] Parasuraman, A., Zeithaml, V.A., Malhotra, A. (2005). E-S-QUAL: A Multiple-item scale for assessing electronic service quality, Journal of Service Research, 7(3), 213-33.

[11] Yoo, B., Donthu, N. (2001). Developing a scale to measure the perceived quality of an internet shopping site (SITEQUAL), Quarterly Journal of Electronic Commerce, 2(1), 31-45.

[12] Long, M., McMellon, C. (2004). Exploring the determinants of retail service quality on the internet, The Journal of Services Marketing, 18(1), 78-90.

[13] Zeithaml, V.A., Parasuraman, A., Malhotra, A. (2002). Service quality delivery through websites: A critical review of extent knowledge, Journal of Academy of Marketing Science, 30(4), 362-375. 
[14] Wolfinbarger, M., Gilly, M.C. (2003). e-TailQ: Dimensionalizing, measuring and predicting e-tail quality, Journal of Retailing, 27(3), 183-98.

[15] Cho, N., Park, S. (2001). Development of electronic commerce user-consumer satisfaction index (ECUSI) for internet shopping, Industrial Management + Data Systems, 101(8/9), 400-405.

[16] Kim S., Stoel, L. (2004). Apparel retailers: Website quality dimensions and satisfaction, Journal of Retailing and Consumer Services, 11, 109-117.

[17] Ha S., Stoel, L. (2012). Online apparel retailing: Roles of e-shopping quality and experiential e-shopping motives, Journal of Service Management, 23(2), 197-215.

[18] Kim, M., Kim, J.H., Lennon, S.J. (2006). Online service attributes available on apparel retail websites: An E-SQUAL approach, Managing Service Quality, 16(1), 51-77.

[19] Park, J.H., Stoel, L. (2002). Apparel shopping on the internet: Information availability on US apparel merchant websites, Journal of Fashion Marketing and Management, 6,(2), 158-176.

[20] Rayman, D., Burns, D.J., Nelson, C.N. (2011). Apparel product quality: Its nature and measurement, Journal of Global Academy of Marketing Science, 21(1), 66-75.

[21] Abraham-Murali, L., Littrell, M.A. (1995). Consumers perception of apparel quality over time: an exploratory study, Clothing and Textile Research Journal, 13(3), 149158

[22] Forsythe, S. (1991). Effect of private, designer and national brand name on shoppers' perception of apparel quality and price, Clothing and Textiles Research Journal, 9, 1-6

[23] North, E.J., Vos, R.B., Kotzé,T. (2003). The importance of apparel product attributes for female buyers, Journal of Family Ecology and Consumer Sciences, 31, 41-51.

[24] Baybars, M., Ustundagli, E. (2011). Attitudes toward online shopping from the aspects of personal characteristics and shopping motive through a developing concept: Private shopping, International Journal of Business and Management Studies, 3(2), 201-210.

[25] Martinez B, (2011). An Analysis of The Impacts of Consumer Shopping Characteristics and Perceived Website Quality on Purchase Intention from a Private Sales Site, (MSc Thesis), The University of Georgia.

[26] Saricam, C. (2015). Acceptance of apparel private sale sites by consumers: application of original and extended technology acceptance model, The Journal of The Textile Institute, 106(10), 1059-1070

[27] Chan, F.T.S., Chan, H.K., (2010). An AHP model for selection of suppliers in the fast changing fashion market, International Journal of Advanced Manufacturing Technology, 51,1195-1207.

[28] Chiang, W.K., Li, Z. (2010). An analytic hierarchy process approach to assessing consumers' distribution channel preference, International Journal of Retail and Distribution Management, 38(2), 78-96.

[29] Saaty, T.L. (1980). The analytic hierarchy process. McGraw-Hill,New York, NY

[30] Hasan, L., Abuelrub, E. (2011). Assessing the quality of websites, Applied Computing and Informatics, 9, 11-29.

[31] Kong, F., Liu, H. (2005). Applying fuzzy analytic hierarchy process to evaluate success factors of e-commerce, International Journal of Information and Systems Sciences, 1(3/4), 406-412.
[32] Cebi, S. (2013). A quality evaluation model for the design quality of online shopping websites, Electronic Commerce Research and Applications, 12, 124-135.

[33] Huang, Y.K., Feng, C.M., (2007). Modelling the determinants of logistics service quality on retailing delivery service for online shopping, 2007 Internatinal Conference on Wireless Communications, Networking and Mobile Computing, WICOM 2007, 21-25 September 2007, China, 3338-3341.

[34] Liu, C., Huang, Y. (2013). Prioritizing value measures of auction websites through users' perspectives, International Journal of Electronic Business Management, 11(2), 144-155.

[35] Calisir, F., Bayraktaroglu, A.E., Gumussoy, C.A., Topcu, Y.I., Mutlu, T.(2010). The relative importance of usability and functionality factors for online auction and shopping websites, Online Information Review, 34(3), 420-439.

[36] Ku, E.C.S., Fan, Y.F. (2009). The decision making in selecting online travel agencies: An application of Analytic Hierarchy Process, Journal of Travel \& Tourism Marketing, 26(5/6), 482-493.

[37] Köksal, M.H. (2007). Consumer behaviour and preferences regarding Children's Clothing in Turkey, Journal of Fashion Marketing and Management, 11(1), 69-81.

[38] Chamodrakas, I., Batis, D., Martakos, D., (2010). Supplier selection in electronic marketplaces using satisficing and Fuzzy AHP, Expert Systems with Applications, 37, 490498.

[39] Tam, M.C.Y., Tummala, V.M.R. (2001). An application of the AHP in vendor selection of a telecommunications system, Omega, 29, 171-182.

[40] Ohta, K., Kobashi, G., Takano, S., Kagaya, S., Yamada, H., Minakami, H., Yamamura, E. (2007). Analysis of the geographical accessibility of neurosurgical emergency hospitals in Sapporo city using GIS and AHP, International Journal of Geographical Information Science, 21(6), 687698.

[41] Pecchia, L., Martin, J.L., Ragozzino, A., Vanzanella, C., Scognamiglio, A., Mirarchi, L., Morgan, S.P., Pecchia et al. (2013). User needs elicitation via Analytic Hierarchy Process (AHP). A case study on a computed tomography (CT) scanner BMC, Medical Informatics and Decision Making, 13(2), 1-11.

[42] Jones, S., Tefe, M, Appiah-Opoku, S. (2013). Proposed framework for sustainability screening of urban transport projects in developing countries: A case study of Accra, Ghana, Transportation Research, Part A, 49, 21-34.

[43] Miller, G.A., (1956). The magical number seven plus or minus two: some limits on our capacity for processing information. Psychological Review, 63, 81-97.

[44] Saaty, T.L., (2008). Decision making with the analytic hierarchy process, International Journal of Services Sciences, 1(1), 83-98.

[45] Awasthi, A., Omrani, H., (2009). A hybrid approach based on AHP and belief theory for evaluating sustainable transportation solutions, International Journal of Global Issues, 9(3), 212-226.

[46] Sharma, A., Sheth, J.N. (2004). Web-based marketing: The coming revolution in marketing thought and strategy, Journal of Business Research, 57(7),696-702. 
[47] Yang,Z., Fang, X. (2004). Online service quality dimensions and their relationships with satisfaction: $A$ content analysis of customer reviews of securities brokerage services, International Journal of Service Industry Management, 15(3), 302-326.

[48] Turquality Project: Consumer Behavior Market Research Turkish Apparel Industry (Turquality Projesi Tüketici Alışkanlıkları Pazar Araştırması Türkiye Hazır Giyim Sektörü)(2007)
http://www.itkib.org.tr/ihracat/TurqualityRaporlar/dosyalar/ ITKIB_HazirGiyim_T\%C3\%BCketiciArastirmasi_ Turk\%C4\%B1ye.pdf, last accessed, 24.12.201 